\title{
Soil Fertility Status of Majhwa Block of Mirzapur District of Eastern UP, India
}

\author{
S.N. Singh ${ }^{1}$, A.M. Latare ${ }^{2 *}$ and S.K. Singh ${ }^{2}$ \\ ${ }^{1}$ BHU-Krishi Vigyan Kendra, Institute of Agricultural Sciences, Barkachha, \\ Mirzapur, UP, 231001, India \\ ${ }^{2}$ Department of Soil Science and Agricultural Chemistry, Institute of Agricultural Sciences, \\ Banaras Hindu University, Varanasi, UP, 221005, India \\ *Corresponding author
}

\section{A B S T R A C T}

\section{Keywords}

Soil fertility, Micronutrients, Water soluble cations, Majhwa, Mirzapur.

Article Info

Accepted:

21 August 2017 Available Online: 10 September 2017
Soil samples were collected from different villages of Majhwa Block of Mirzapur district. The results showed that the available $\mathrm{N}, \mathrm{P}, \mathrm{K}$ and $\mathrm{S}$ content in surface $(0-20 \mathrm{~cm})$ soils was higher as compared to sub surface $(20-40 \mathrm{~cm})$. The mean content of available $\mathrm{N}, \mathrm{P}, \mathrm{K}$ and $\mathrm{S}$ in surface soils $(0-20 \mathrm{~cm})$ were $306,18.4,229$ and $9.8 \mathrm{~kg} \mathrm{ha}^{-1}$, whereas, in subsurface soil $(20-40 \mathrm{~cm})$ it was $241,20.4,189$ and $8.57 \mathrm{~kg} \mathrm{ha}^{-1}$, respectively. The mean DTPA extractable $\mathrm{Fe}, \mathrm{Cu}, \mathrm{Mn}, \mathrm{Zn}$ and hot water soluble $\mathrm{B}$ content followed the similar pattern of distribution in the surface and subsurface soils. The maximum $\mathrm{Fe}, \mathrm{Cu}, \mathrm{Mn}, \mathrm{Zn}$ and $\mathrm{B}$ content in top soils was $15.2,6.2,3.11,2.63$ and $1.47 \mathrm{mg} \mathrm{kg}^{-1}$, respectively. The mean values of water soluble cations $\mathrm{Ca}, \mathrm{Mg}, \mathrm{Na}$ and $\mathrm{K}$ in surface soils $(0-20 \mathrm{~cm})$ were 19.3 , 9.59, 9.07 and $11.7 \mathrm{~m} \mathrm{eq} \mathrm{L}^{-1}$, respectively. The available B and $\mathrm{Zn}$ content in surface soils and available $\mathrm{N}$ and organic carbon content in subsurface soils were positively and significantly correlated.

\section{Introduction}

Soil is a critical component for the proper functioning of agricultural system. The fertility of a soil plays an important role in sustainable crop production. Due to continuous rice-wheat cultivation in IndoGangetic region, fertility of soil is deteriorating, raising a serious concern about the sustainability of Indian agriculture. The introduction of high yielding varieties, extensive tillage and imbalanced use of chemical fertilizers and pesticides caused disturbance in soil ecosystem. In post green revolution era there has been a continuous increase in use of chemical fertilizers, irrigation along with modern high yielding varieties (Pathak, 2010). However, recent reports suggest a declining trend in production of rice and wheat in South Asia (Ladha et al., 2003) which is mainly attributed to deficiency of micronutrients in soil.

It has been reported that deficiencies of available major and micronutrients are widespread in soils of Mirzapur districts of eastern Uttar Pradesh (Singh and Kumar, 2012). Deficiency of sulphur and boron to a tune of 63 and $61 \%$ have been reported 
(Singh et al., 2015) in soils of Mirzapur district.

The increasing demand of food grain has forced farmers to use high doses of chemical fertilizers. Imbalanced use of chemical fertilizers is a serious threat to sustainable agricultural production system. Soil test-based fertilizer recommendation and management is an effective tool for increasing productivity of agricultural soils (Srinivasarao et al., 2010; Sahrawat et al., 2010). However, major constraints impede wide scale adoption of soil testing in most developing countries. Soil testing provides information regarding nutrient availability in soils which forms the basis for the fertilizer recommendations for maximizing crop yields (Doneriya et al., 2013). The objective of this study was to prepare a comprehensive database about the fertility status of the soils of Majhwa block of Mirzapur. So as to arrest the declining trend in productivity by supplying balanced nutrition in crop production. The soils of the study regions are more prone to submergence due to frequent flood occurring in Ganga River. Thus the study of surface $(0-20 \mathrm{~cm})$ as well as subsurface $(20-40 \mathrm{~cm})$ soils becomes important for this particular area.

\section{Materials and Methods}

\section{Site description and collection of sample}

The Majhwa block is located in Vindhyan region of district Mirzapur, Uttar Pradesh. The soils of the block are red in colour which are formed on granitic parent material representing Alfisols. The detailed description of the study locations has been given in table 1 .

A total of six villages were selected for this study. The detailed site description along with cropping pattern is presented in table 1 . Forty soil samples from surface $(0-20 \mathrm{~cm})$ and subsurface $(20-40 \mathrm{~cm})$ were collected from every village representing total 480 samples.
The soil bulk density was estimated using the soil core sampler method (Blake, 1965). The samples were air dried, processed and passed through a $2 \mathrm{~mm}$ sieve. In general, the texture of the soils was either sandy loam or sandy clay loam. The soil $\mathrm{pH}$ and electrical conductivity (EC) were recorded in 1:2.5 soil to water suspension (Jackson, 1973). Different soil chemical properties determined were: soil organic carbon (OC) content by chromic acid wet oxidation method (Walkley and Black, 1934), available nitrogen (N) by alkaline potassium permanganate method (Subbiah and Asija, 1956), available phosphorus (P) spectrophotometrically (Olsen et al., 1954), available potassium (K) by flame photometrically (Hanway and Heidel, 1952), $0.15 \% \quad \mathrm{CaCl}_{2}$ extractable sulphur (S) by turbiditimetrically (Chesin and Yein, 1951), soil available micronutrients iron $(\mathrm{Fe})$, manganese $(\mathrm{Mn})$, copper $(\mathrm{Cu})$ and zinc $(\mathrm{Zn})$ by DTPA-extraction method (Lindsay and Norwell, 1978). Hot water soluble B in soil was extracted using $0.02 M \mathrm{CaCl}_{2}$ (Aitken et al., 1987). Water soluble ions were determined in 1:2.5 soil to water suspension, whereas, exchangeable ions in neutral normal ammonium acetate extract (Richards, 1954). The data on soil properties were correlated with nutrient status of the soil using SPSS.

\section{Results and Discussion}

\section{Physico-chemical properties}

In comparison to subsurface soil, the bulk density and particle density of surface soils $(0-20 \mathrm{~cm})$ was lower and it ranged from 1.211.39 and $2.40-2.48 \mathrm{Mg} \mathrm{m}^{3}$, respectively, whereas in subsurface soils $(20-40 \mathrm{~cm})$ it varied between $1.36-1.42$ and $2.43-2.51 \mathrm{Mg}$ $\mathrm{m}^{3}$, respectively (Table 2 ). The mean bulk density in surface and subsurface soil was 1.31 and $1.39 \mathrm{Mg} \mathrm{m}^{-3}$, respectively, whereas, particle density was 2.44 and $2.48 \mathrm{Mg} \mathrm{m}^{-3}$, respectively. The highest bulk density and particle density was recorded at Kachhwa and 
Shivrani, respectively. The water holding capacity varied from 42 to $47 \%$ in surface soil and 39 to $45 \%$ in subsurface soil. The maximum water holding capacity in surface and subsurface soil was recorded in Kevtari $(47 \%)$ and Shivrani $(45 \%)$ village, respectively, whereas, the mean WHC was 45.2 and $41.3 \%$, respectively.

The $\mathrm{pH}$ of surface and subsurface soils ranged between 7.5 to 8.2 and 7.8 to 8.4 with a mean of 7.78 and 8.08 , respectively (Table 2). The maximum $\mathrm{pH}$ was 8.2 and 8.4 in surface and subsurface soil, respectively in Kevtari village. The EC ranged between 0.49 to 1.21 and 0.36 to $1.12 \mathrm{dS} \mathrm{m}^{-1}$ with a mean of 0.84 and $0.73 \mathrm{dS} \mathrm{m}^{-1}$ in surface and subsurface soil, respectively. The organic carbon content in soil ranged between 0.61 to 0.79 and 0.49 to $0.72 \%$ with a mean of 0.69 and $0.58 \%$, respectively in surface and subsurface soil. The maximum organic carbon content was found in Shivrani in both surface and subsurface soil. The higher $\mathrm{pH}$ in soil might be due to presence of various salts which is also clearly visible from the $\mathrm{EC}$ values.

The soils had organic carbon content in medium range, this might be due to addition of organic manure by the farmers. Tiwari et al., (2003) reported that $\mathrm{C} / \mathrm{N}$ ratio of the Vindhyan soils was higher in the low-laying areas than that of upland with terrace containing sand stone and lime stone shale. Also, high temperature during summer might be responsible for the rapid decomposition of organic matter, thus resulting in low organic $\mathrm{C}$ content of these soils.

\section{Available major nutrients}

The available $\mathrm{N}, \mathrm{P}, \mathrm{K}$ and $\mathrm{S}$ content in the surface soil $(0-20 \mathrm{~cm})$ ranged between 287 $349,17.3-19.3,216-257$ and 8.93-10.3 with a mean of $306,18.4,229$ and $9.80 \mathrm{~kg} \mathrm{ha}^{-1}$, respectively (Table 3 ). The maximum value of available $\mathrm{N}, \mathrm{P}$ and $\mathrm{K}$ in surface soils was recorded in Bajaha, whereas, the maximum available sulphur was found in Kachhawa. The data shows that the available N, P and K content in surface soil was in medium category while, the soils had low available $\mathrm{S}$. The available $\mathrm{N}, \mathrm{K}$ and $\mathrm{S}$ content in surface soils was higher than the subsurface soil, while the content of available $\mathrm{P}$ in subsurface soil was higher than surface soil. The available $\mathrm{N}, \mathrm{P}, \mathrm{K}$ and $\mathrm{S}$ content in subsurface soils ranged between $216-278,19.6$ to 21.2 , 169 to 211 and 7.21 to $9.61 \mathrm{~kg} \mathrm{ha}^{-1}$ with a mean of 241, 20.4, 189 and $8.57 \mathrm{~kg} \mathrm{ha}^{-1}$, respectively. The available $K$ content in surface soil $(0-20 \mathrm{~cm})$ showed a positive and significant correlation $(\mathrm{r}=0.91 *)$ with available $\mathrm{P}$ content. In subsurface soil (20-40 $\mathrm{cm})$ available $\mathrm{N}$ content was positively significantly correlated with organic carbon. The soils of these regions are formed due to deposition of recent alluvium, therefore, they are rich in available $\mathrm{N}, \mathrm{P}$ and $\mathrm{K}$. The soils had organic carbon content in medium range, since organic matter content is an indicator of available $\mathrm{N}$ status of soils, thus the soils of the investigating area are also dominantly medium in respect of their available $\mathrm{N}$ (Verma et al., 2005). The medium range of soils available $\mathrm{P}$ under study area may be mostly due to past fertilization, $\mathrm{pH}$, organic matter content, texture and various soil management and agronomic practices (Elzinga and Sparks, 2007). Adequate level of available $\mathrm{K}$ in Alfisol of the study area may be ascribed to the prevalence of K-rich clay minerals like illite and kaolinite (Seal et al., 2006)

\section{Available micronutrients}

The DTPA extractable $\mathrm{Fe}, \mathrm{Mn}, \mathrm{Zn}$ and $\mathrm{Cu}$ content in surface soils ranged from 10.6 to $15.2,4.6$ to $16.2,2.53$ to 3.11 and 1.82 to 2.63 $\mathrm{mg} \mathrm{kg}^{-1}$ with a mean of 13.6, 5.13, 2.78 and $2.11 \mathrm{mg} \mathrm{kg}^{-1}$, respectively (Table 4). 
Table.1 Detailed description of the study locations

\begin{tabular}{|l|l|l|l|l|}
\hline Location No. & Village Name & Previous crop & Kharif crop & Rabi crops \\
\hline 1 & Kachhawa & Mung & Rice, Maize, Sesamum, Mung, Urd & Wheat, Barley, Brinjal, Chilli, Onion, Cauliflower \\
\hline 2 & Bajaha & Urd & mung, Urd, Surajmukhi & Wheat, Brinjal, Vegetable Pea, Mustard \\
\hline 3 & Baraini & Pumpkin & Rice, Lady's finger, Pumpkin & Wheat, Potato, tomato, Lentil \\
\hline 4 & Mitai & Bottlegourd & Rice, Bottle gourd, Sponge gourd & Wheat, Garlic, Chilli, Cauliflower \\
\hline 5 & Shivrani & Ladys finger & Rice, Pumpkin, Lady’s finger & Wheat, Brinjal, Onion, Mustard \\
\hline 6 & Kevtari & Bitter gourd & Rice, Lobia, Pumpkin, bitter gourd & Wheat, Gram, Vegetable Pea \\
\hline
\end{tabular}

Table.2 Physico-chemical properties of soils of Mirzapur district

\begin{tabular}{|c|c|c|c|c|c|c|c|c|c|c|c|c|}
\hline \multirow{2}{*}{ Village } & \multicolumn{2}{|c|}{$\mathrm{BD}\left(\mathrm{Mg} \mathrm{m}^{3}\right)$} & \multicolumn{2}{|c|}{$\mathrm{PD}\left(\mathrm{Mg} \mathrm{m}^{3}\right)$} & \multicolumn{2}{|c|}{ WHC (\%) } & \multicolumn{2}{|c|}{$\mathrm{pH}$} & \multicolumn{2}{|c|}{$\mathrm{EC}\left(\mathrm{dS} \mathrm{m} \mathrm{m}^{-1}\right)$} & \multicolumn{2}{|c|}{$\mathrm{OC}(\%)$} \\
\hline & $0-20$ & $20-40$ & $0-20$ & $20-40$ & $0-20$ & $20-40$ & $0-20$ & $20-40$ & $0-20$ & $20-40$ & $0-20$ & $20-40$ \\
\hline Kachhawa & 1.22 & 1.42 & 2.40 & 2.43 & 42 & 39 & 7.6 & 7.9 & 0.49 & 0.36 & 0.65 & 0.51 \\
\hline Bajaha & 1.21 & 1.36 & 2.44 & 2.48 & 46 & 43 & 7.5 & 7.8 & 0.88 & 0.76 & 0.72 & 0.63 \\
\hline Baraini & 1.36 & 1.39 & 2.41 & 2.46 & 44 & 41 & 7.9 & 8.3 & 0.95 & 0.82 & 0.68 & 0.49 \\
\hline Mitai & 1.32 & 1.37 & 2.44 & 2.49 & 46 & 42 & 7.6 & 7.9 & 0.52 & 0.49 & 0.66 & 0.59 \\
\hline Shivrani & 1.39 & 1.41 & 2.48 & 2.51 & 46 & 45 & 7.9 & 8.2 & 0.99 & 0.83 & 0.79 & 0.72 \\
\hline Kevtari & 1.36 & 1.38 & 2.44 & 2.49 & 47 & 40 & 8.2 & 8.4 & 1.21 & 1.12 & 0.61 & 0.52 \\
\hline Range & $(1.21-1.39)$ & $(1.36-1.42)$ & $(2.40-2.48)$ & $(2.43-2.51)$ & $(42-47)$ & $(39-43)$ & $(7.5-8.2)$ & $(7.8-8.4)$ & $(0.49-1.21)$ & $(0.36-1.12)$ & $(0.61-0.79)$ & $(0.49-0.72)$ \\
\hline Mean & 1.31 & 1.39 & 2.44 & 2.48 & 45.2 & 41.3 & 7.78 & 8.08 & 0.84 & 0.73 & 0.69 & 0.58 \\
\hline SD & 0.08 & 0.02 & 0.03 & 0.03 & 1.83 & 1.63 & 0.26 & 0.25 & 0.28 & 0.27 & 0.06 & 0.09 \\
\hline Variance & 0.01 & 0.00 & 0.00 & 0.00 & 3.37 & 2.67 & 0.07 & 0.06 & 0.08 & 0.07 & 0.00 & 0.01 \\
\hline
\end{tabular}

Table.3 Available N, P, K and S in soils of Mirzapur district

\begin{tabular}{|c|c|c|c|c|c|c|c|c|}
\hline \multirow[t]{2}{*}{ VIllage } & \multicolumn{2}{|c|}{ Available $\mathrm{N}\left(\mathrm{kg} \mathrm{ha}^{-1}\right)$} & \multicolumn{2}{|c|}{ Available $\mathrm{P}\left(\mathrm{kg} \mathrm{ha}^{-1}\right)$} & \multicolumn{2}{|c|}{ Available $\mathrm{K}\left(\mathrm{kg} \mathrm{ha}^{-1}\right)$} & \multicolumn{2}{|c|}{ Available S $\left(\mathrm{kg} \mathrm{ha}^{-1}\right)$} \\
\hline & $0-20$ & $20-40$ & $0-20$ & $20-40$ & $0-20$ & $20-40$ & $0-20$ & $20-40$ \\
\hline Kachhawa & 287 & 225 & 18.2 & 20.1 & 220 & 186 & 10.3 & 9.12 \\
\hline Bajaha & 349 & 278 & 19.3 & 21.2 & 257 & 201 & 8.93 & 7.21 \\
\hline Baraini & 300 & 216 & 18.6 & 20.3 & 221 & 174 & 9.98 & 8.34 \\
\hline Mitai & 291 & 260 & 18.3 & 20.6 & 236 & 211 & 9.69 & 8.76 \\
\hline Shivrani & 313 & 237 & 18.8 & 20.6 & 223 & 192 & 10.2 & 9.61 \\
\hline Kevtari & 296 & 229 & 17.3 & 19.6 & 216 & 169 & 9.67 & 8.37 \\
\hline Range & $(287-349)$ & $(216-278)$ & $(17.3-19.3)$ & $(19.6-21.2)$ & $(216-257)$ & $(169-211)$ & $(8.93-10.3)$ & $(7.21-9.61)$ \\
\hline Mean & 306 & 241 & 18.4 & 20.4 & 229 & 189 & 9.80 & 8.57 \\
\hline SD & 22.9 & 23.5 & 0.67 & 0.54 & 15.4 & 15.9 & 0.50 & 0.82 \\
\hline Variance & 524 & 554 & 0.454 & 0.292 & 237 & 254 & 0.246 & 0.673 \\
\hline
\end{tabular}


Table.4 DTPA extractable Fe, Mn, Zn, Cu and B in soils of Mirzapur district

\begin{tabular}{|c|c|c|c|c|c|c|c|c|c|c|}
\hline \multirow[t]{2}{*}{ Village } & \multicolumn{2}{|c|}{ Available Fe $\left(\mathrm{mg} \mathrm{kg}^{-1}\right)$} & \multicolumn{2}{|c|}{ Available $\mathrm{Mn}\left(\mathrm{mg} \mathrm{kg}^{-1}\right)$} & \multicolumn{2}{|c|}{ Available $\mathrm{Zn}\left(\mathrm{mg} \mathrm{kg}^{-1}\right)$} & \multicolumn{2}{|c|}{ Available $\mathrm{Cu}\left(\mathrm{mg} \mathrm{kg}^{-1}\right)$} & \multicolumn{2}{|c|}{ Available B $\left(\mathrm{mg} \mathrm{kg}^{-1}\right)$} \\
\hline & $0-20$ & $20-40$ & $0-20$ & $20-40$ & $0-20$ & $20-40$ & $0-20$ & $20-40$ & $0-20$ & $20-40$ \\
\hline Kachhawa & 15.1 & 12.3 & 6.2 & 3.3 & 2.61 & 1.26 & 1.93 & 1.21 & 1.26 & 0.96 \\
\hline Bajaha & 14.3 & 11.2 & 5.2 & 2.6 & 2.81 & 1.23 & 1.82 & 1.16 & 1.39 & 1.11 \\
\hline Baraini & 14.6 & 12.3 & 4.6 & 3.9 & 3.11 & 1.62 & 2.12 & 1.44 & 1.46 & 1.02 \\
\hline Mitai & 15.2 & 13.1 & 5.3 & 5.1 & 2.53 & 1.24 & 2.63 & 1.32 & 1.23 & 0.97 \\
\hline Shivrani & 11.6 & 10.9 & 4.6 & 3.9 & 2.91 & 1.46 & 2.36 & 1.42 & 1.47 & 1.03 \\
\hline Kevtari & 10.6 & 9.3 & 4.9 & 2.9 & 2.72 & 1.43 & 1.82 & 0.98 & 1.29 & 1.04 \\
\hline Range & $\begin{array}{c}(10.6- \\
15.2)\end{array}$ & $\begin{array}{l}(9.3- \\
13.1)\end{array}$ & $(4.6-6.2)$ & $(2.6-5.1)$ & $\begin{array}{c}(2.53- \\
3.11)\end{array}$ & $\begin{array}{c}(1.23- \\
1.62)\end{array}$ & $(1.82-2.63)$ & $(0.98-1.44)$ & $\begin{array}{c}(1.23- \\
1.47)\end{array}$ & $(0.96-1.11)$ \\
\hline Mean & 13.6 & 11.5 & 5.13 & 3.62 & 2.78 & 1.37 & 2.11 & 1.26 & 1.35 & 1.02 \\
\hline SD & 1.96 & 1.35 & 0.60 & 0.90 & 0.21 & 0.16 & 0.33 & 0.17 & 0.10 & 0.05 \\
\hline Variance & 3.86 & 1.83 & 0.36 & 0.80 & 0.04 & 0.02 & 0.11 & 0.03 & 0.01 & 0.00 \\
\hline
\end{tabular}

Table.5 Water soluble cations ( $\mathrm{m} \mathrm{eq} \mathrm{L}^{-1}$ ) of the Mirzapur district

\begin{tabular}{|c|c|c|c|c|c|c|c|c|c|c|}
\hline \multirow[t]{2}{*}{ Village } & \multicolumn{2}{|c|}{$\mathrm{Ca}$} & \multicolumn{2}{|c|}{$\mathrm{Mg}$} & \multicolumn{2}{|c|}{$\mathrm{Na}$} & \multicolumn{2}{|c|}{$\mathrm{K}$} & \multicolumn{2}{|c|}{ Total cation } \\
\hline & $0-20$ & $20-40$ & $0-20$ & $20-40$ & $0-20$ & $20-40$ & $0-20$ & $20-40$ & $0-20$ & $20-40$ \\
\hline Kachhawa & 18.1 & 15.7 & 10.2 & 9.36 & 9.24 & 8.36 & 12 & 12 & 49.5 & 45.4 \\
\hline Bajaha & 19.2 & 18.6 & 9.38 & 8.96 & 8.96 & 8.24 & 11.6 & 11.6 & 49.2 & 47.4 \\
\hline Baraini & 20.1 & 19.3 & 9.69 & 8.76 & 9.12 & 8.32 & 10.3 & 10.3 & 49.2 & 46.7 \\
\hline Mitai & 19.6 & 18.3 & 10.4 & 9.62 & 8.99 & 8.12 & 11.9 & 11.9 & 50.0 & 48.0 \\
\hline Shivrani & 18.9 & 16.7 & 9.21 & 9.63 & 9.16 & 8.38 & 12.2 & 12.1 & 49.3 & 48.2 \\
\hline Kevtari & 20.0 & 18.4 & 8.73 & 7.96 & 8.96 & 8.39 & 11.9 & 10.6 & 49.6 & 44.3 \\
\hline Range & $(18.0-20.1)$ & $(15.7-19.3)$ & $(8.73-10.4)$ & $\begin{array}{l}(7.96- \\
9.63)\end{array}$ & $\begin{array}{l}(8.96- \\
9.24)\end{array}$ & $\begin{array}{c}(8.12- \\
8.39)\end{array}$ & $\begin{array}{c}(10.3- \\
12.2)\end{array}$ & $\begin{array}{c}(10.3- \\
12.1)\end{array}$ & $(49.2-50.0)$ & $\begin{array}{r}(44.3- \\
48.2)\end{array}$ \\
\hline Mean & 19.3 & 18.1 & 9.59 & 9.05 & 9.07 & 8.30 & 11.7 & 11.4 & 49.5 & 46.7 \\
\hline $\mathrm{SD}$ & 0.75 & 1.24 & 0.61 & 0.64 & 0.12 & 0.10 & 0.69 & 0.77 & 0.30 & 1.53 \\
\hline Variance & 0.56 & 1.53 & 0.37 & 0.41 & 0.01 & 0.01 & 0.48 & 0.60 & 0.09 & 2.36 \\
\hline
\end{tabular}


Fig.1 Location of Majhwa block of Mirzapur district in Uttar Pradesh

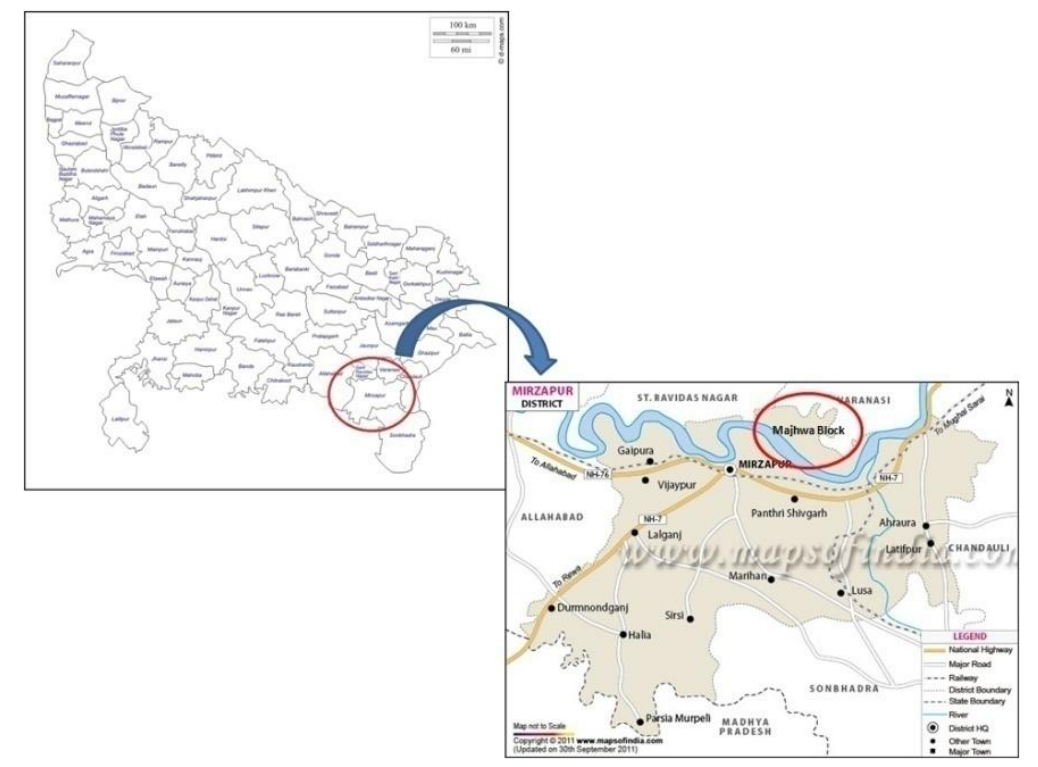

The maximum Fe (15.2 $\left.\mathrm{mg} \mathrm{kg}^{-1}\right)$ and $\mathrm{Zn}(3.11$ $\mathrm{mg} \mathrm{kg}{ }^{-1}$ ) content in surface soil was found in Mitai, while the highest content of Mn (16.2 $\left.\mathrm{mg} \mathrm{kg}{ }^{-1}\right)$ and $\mathrm{Cu}\left(2.63 \mathrm{mg} \mathrm{kg}^{-1}\right)$ was recorded in Kachhawa and Baraini, respectively. In subsurface soil $(20-40 \mathrm{~cm})$ the DTPA extractable $\mathrm{Fe}, \mathrm{Mn}, \mathrm{Cu}$ and $\mathrm{Zn}$ content ranged between 9.30 to $13.1,2.6$ to $5.1,1.23$ to 1.62 and 0.98 to $1.44 \mathrm{mg} \mathrm{kg}^{-1}$, respectively. The study demonstrated that DTPA extractable Fe, $\mathrm{Mn}, \mathrm{Zn}$ and $\mathrm{Cu}$ content in subsurface soils was sufficient having a mean of 11.5, 3.62, 1.37 and $1.26 \mathrm{mg} \mathrm{kg}^{-1}$, respectively. The available $\mathrm{B}$ content in surface and subsurface soil ranged between 1.23 to 1.47 and 0.96 to $1.11 \mathrm{mg} \mathrm{kg}^{-1}$, with a mean of 1.35 and 1.02 mg $\mathrm{kg}^{-1}$, respectively. The maximum available $B$ content in surface $\left(1.47 \mathrm{mg} \mathrm{kg}^{-1}\right)$ and sub-surface soils (1.11 $\left.\mathrm{mg} \mathrm{kg}^{-1}\right)$ was found in Shivrani and Bajaha village. The surface soil had higher content of available $\mathrm{Fe}, \mathrm{Mn}, \mathrm{Cu}, \mathrm{Zn}$ and $\mathrm{B}$ compared to sub surface soil. The DTPA extractable $\mathrm{Zn}$ content in surface soil $(0-20 \mathrm{~cm})$ had positive and highly significant correlation $\left(\mathrm{r}=0.93^{* *}\right)$ with available B. Critical limits recommended by Lindsay and Norvell (1978) for DTPA extractable, $\mathrm{Fe}, \mathrm{Mn}, \mathrm{Zn}$ and $\mathrm{Cu}$ are 4.5, 2.0,
0.6 and $0.2 \mathrm{mg} \mathrm{kg}^{-1}$, respectively. The sufficient amount of micronutrients in soils of vegetables and pulse growing areas of Mirzapur were also reported by Singh and Kumar (2012). Singh and Singh (2016) studied the nutrient status of red soils of Vindhyan region, they also found that the DTPA extractable $\mathrm{Fe}, \mathrm{Mn}, \mathrm{Cu}$ and $\mathrm{Zn}$ content was above critical limits for its deficiency as per given by Lindsay and Norvell (1978).

\section{Water soluble cations}

The water soluble $\mathrm{Ca}, \mathrm{Mg}, \mathrm{Na}$ and $\mathrm{K}$ content in surface soils ranged from 18.0 to 20.1, 8.73 to $10.4,8.96$ to 9.24 and 10.3 to 12.2 with a mean of $19.3,9.59,9.07$ and $11.7 \mathrm{~m} \mathrm{eq} \mathrm{L}^{-1}$, respectively (Table 5). The maximum water soluble $\mathrm{Ca}, \mathrm{Mg}, \mathrm{Na}$ and $\mathrm{K}$ content in surface soil was recorded in Baraini, Mitai, Kachhawa and Shivrani, respectively. In subsurface soil $(20-40 \mathrm{~cm})$ the water soluble $\mathrm{Ca}, \mathrm{Mg}, \mathrm{Na}$ and $\mathrm{K}$ content ranged between 15.7 to $19.3,7.96$ to $9.63,8.12$ to 8.39 and 10.3 to $12.1 \mathrm{~m} \mathrm{eq} \mathrm{L}^{-1}$, respectively. The data showed that water soluble cation content in both surface and subsurface soil varied in following order $\mathrm{Ca}>\mathrm{K}>\mathrm{Mg}>\mathrm{Na}$. The mean 
water soluble $\mathrm{Ca}, \mathrm{Mg}, \mathrm{Na}$ and $\mathrm{K}$ content of subsurface soil was $18.1,9.05,8.30$ and 11.4 $\mathrm{m}$ eq $\mathrm{L}^{-1}$, respectively. The total cationic content in surface and subsurface soil ranged between 49.2 to 50.0 and 44.3 to $48.2 \mathrm{~m} \mathrm{eq} \mathrm{L}^{-1}$, with a mean of 49.5 and $46.7 \mathrm{~m} \mathrm{eq} \mathrm{L}^{-1}$, respectively. The maximum total cationic concentration in surface $\left(50.0 \mathrm{~m} \mathrm{eq} \mathrm{L}^{-1}\right)$ and sub-surface soils ( $48.2 \mathrm{~m} \mathrm{eq} \mathrm{L}^{-1}$ ) was found in Mitai and Shivrani village. The soils of the study regions are affected due to frequent flood occurring in the Ganga River. The water soluble cations in study sites are higher because of accumulated clay of Ganga River which is rich in water soluble cations. The samples were collected in the month of May, when rate of evaporation in higher and salts accumulate on the soil surface with evaporating water. Thus the study sites showed higher content of water soluble cations.

The soils of Mjhawa Block of Mirzapur district had a $\mathrm{pH}$ of 7.5 to 8.2 in surface soils and 7.8 to 8.4 in subsurface soils. It contained medium to high organic carbon in surface soils, medium status of available $\mathrm{N}, \mathrm{P}$ and $\mathrm{K}$ and low status of available $\mathrm{S}$. The highest available $\mathrm{N}, \mathrm{P}$ and $\mathrm{K}$ content was in Bajaha village, while highest $S$ was found in Kachhawa. The DTPA extractable Fe, Mn, $\mathrm{Zn}, \mathrm{Cu}$ and $\mathrm{B}$ content in surface as well as subsurface soils was under sufficient category. The highest DTPA extractable Fe, $\mathrm{Mn}, \mathrm{Zn}, \mathrm{Cu}$ and $\mathrm{B}$ content in surface soils was found in Mitai, Kachhawa, Baraini, Mitai and Shivrani village, respectively. The soils were low in available $S$ hence the application of organic matter and gypsum may be recommended for application in fields.

\section{References}

Aitken, R.L., Jeffrey, A.J. and Compton, B.L. 1987. Evaluation of selected extractants for boron in some Queensland soils.
Australian Journal of Soil Research 25, 265-273

Blake, G.R., 1965. Bulk density in methods of soil analysis. Agronomy, No. 9, Part 1 (C.A. Black, Ed.). pp. 374-390.

Chesin, L., and Yein, C.H. 1951. Turbidimetric determination of available sulphur. Soil Science Society of America Proceedings 15, 149-151.

Doneriya, B.S., Meena, R., Meena, V.S., Meena, R.S. and Dadhich R. 2013. Soil fertility status of vegetable and pulses growing area under Marihan block in Vindhyan region of Mirzapur district. An Asian Journal of Soil Science 8(2):286-289.

Elzinga, E.J., and Sparks, D.L. 2007. Phosphate adsorption onto hematite: An in situ ATRFTIR investigation of the effects of $\mathrm{pH}$ and loading level on the mode of phosphate surface complexation. Journal of Colloid and Interface Science 308: 53-70.

Hanway, J.J., and Heidel, H. 1952. Soil analysis method as used in Iowa State College, Soil Testing Laboratory. Iowa Agriculture 54, 1-31.

Jackson, M.L., 1973. Soil Chemical Analysis. Prentice Hall of India Pvt. Ltd., New Delhi.

Ladha, J.K., Dawe, D., Pathak, H., Padre, A.T., Yadav, R.L., Singh, B., Singh, Y., Singh, Y., Singh, P., Kundu, A.L., Sakal, R., Ram, N., Regmi, A.P., Gami, S.K., Bhandari, A.L., Amin, R., Yadav, C.R., Bhattarai, E.M., Das, S., Aggarwal, H.P., Gupta, R.K. and Hobbs, P.R. 2003. How extensive are yield declines in long-term rice-wheat experiments in Asia? Field Crops Research 81: 159-180.

Lindsay, W.L., and Norwell, W.A. 1978. Development of DTPA soil test for zinc, iron, manganese and copper. Soil Science Society of America Journal 42, 421-428. 
Olsen, S.R., Cole, C.V., Watanable, F.S. and Dean, L.A. 1954. Estimation of available phosphorus in soils by extraction with sodium bicarbonate. USDA Circular 939

Pathak, H., 2010. Trend of fertility status of Indian Soils. Current Advances in Agricultural Sciences 2(1): 10-12

Richards, L.A., 1954. Diagnosis and improvement of saline and alkali soils. Handbook No. 60, Oxford and IBH Publishing Company, Calcutta

Sahrawat, K.L., Wani, S.P., Pardhasaradhi, G. and Murthy, K.V.S. 2010. Diagnosis of secondary and micronutrient deficiencies and their management in rainfed agro-ecosystems: Case study from Indian semi-arid tropics. Communications in Soil Science and Plant Analysis 41: 346-360.

Seal, A., Bera, R., Mukhopadhyay, K. and Bhattacharya, P. 2006. Potassium fixation capability of some acid alfisol developed under tropical environment in Eastern India. International Journal of Soil Science 1: 128- 133.

Singh, S., and Kumar, P. 2012. Soil fertility status of vegetables growing area of Varanasi and pulses growing area of Mirzapur. Journal of the Indian Society of Soil Science 60(3): 233-236.

Singh, S.K., Dey, P., Singh, S., Sharma, P.K., Singh, Y.V., Latare, A.M., Singh, C.M., Kumar, D., Kumar, O., Yadav, S.N. and Verma, S.S. 2015. Emergence of Boron and Sulphur Deficiency in Soils of Chandauli, Mirzapur, Sant Ravidas Nagar and Varanasi Districts of Eastern
Uttar Pradesh. Journal of the Indian Society of Soil Science, 63, 200-208.

Singh, S.N., and Singh, R.P. 2016. Nutrient status of red soils of Vindhyan region (District Mirzapur, Uttar Pradesh). Journal of Soils and Crops 26(2):199202.

Srinivasarao, C.H., Wani, S.P., Sahrawat, K.L., Krishnappa, K. and Rajasekhara, Rao, B.K. 2010. Effect of balanced nutrition on yield and economics of vegetable crops in participatory watersheds in Karnataka. Indian Journal of Fertilizers 6: 39-42

Subbiah, B.V., and Asija, G.L. 1956. A rapid procedure for determination of available nitrogen in soils. Current Science 25, 259-260.

Tiwari, R.C., Agarwal, H.P., Maurya, B.R. and Narayan, D. 2003. Organic matter recycling and enrichment. Department of Soil Science and Agricultural Chemistry, Institute of Agricultural Sciences, Banaras Hindu University, Varanasi. Final report of the research project, submitted to ICAR (NATP), New Delhi pp. 36-41.

Verma, V.K., Patel, L.B., Toor, G.S. and Sharma, P.K. 2005. Spatial distribution of macronutrients in soils of arid tract of Punjab. Indian Journal of Agriculture and Biology 7(2): 370- 372.

Walkley, A.J., and Black, I.A. 1934. An examination of the Degtjareff method for determining soil organic matter, and a proposed modification of the chromic acid titration method. Soil Science 37, 29-38.

\section{How to cite this article:}

Singh, S.N., A.M. Latare and Singh, S.K. 2017. Soil Fertility Status of Majhwa Block of Mirzapur District of Eastern UP. Int.J.Curr.Microbiol.App.Sci. 6(9): 2019-2026. doi: https://doi.org/10.20546/ijcmas.2017.609.248 